\title{
Using olive mill wastewater to improve performance in producing electricity from domestic wastewater by using single-chamber microbial fuel cell
}

\author{
Tommy Pepè Sciarria ${ }^{\mathrm{a}, \mathrm{b}}$, Alberto Tenca ${ }^{\mathrm{a}}$, Alessandra D’Epifanio ${ }^{\mathrm{b}}$, Barbara Mecheri ${ }^{\mathrm{b}}$, Giuseppe Merlino ${ }^{\mathrm{c}}$, \\ Marta Barbato ${ }^{\mathrm{c}}$, Sara Borin ${ }^{\mathrm{c}}$, Silvia Licoccia ${ }^{\mathrm{b}}$, Virgilio Garavaglia ${ }^{\mathrm{a}}$, Fabrizio Adani ${ }^{\mathrm{a}, *}$ \\ ${ }^{a}$ RICICLA GROUP, Dipartimento di Scienze Agrarie e Ambientali: Produzione, Territorio, Agroenergia, Via Celoria 2, 20133 Milan, Italy \\ ${ }^{\mathrm{b}}$ NAST Centre E Department of Chemical Science and Technology, University of Rome Tor Vergata, Rome, Italy \\ ${ }^{\mathrm{c}}$ Department of Food Environmental and Nutritional Sciences (DEFENS), University of Milan, Celoria 2, 20133 Milan, Italy
}

\section{H I G H L I G H T S}

- Olive mill wastewater (OMW) represents a problem for its disposal and treatment.

- Single-chamber MFC was used to produce electricity from OMW and wastewater (DW).

- MFCs fed with DW plus OMW gave $0.38 \mathrm{~V}\left(1 \mathrm{k} \Omega\right.$ ) and a power density of $124.6 \mathrm{~mW} \mathrm{~m}^{-2}$.

- TCOD and $\mathrm{BOD}_{5}$ of DW plus OMW mix was reduced of $65 \%$ and $50 \%$ respectively.

- Microbial characterization of electrodes bacterial communities indicate anode differences.

\section{A R T I C L E I N F O}

\section{Article history:}

Received 17 June 2013

Received in revised form 31 July 2013

Accepted 5 August 2013

Available online 14 August 2013

\section{Keywords:}

Biomass treatment

Domestic wastewater

Electricity generation

Microbial fuel cell

Olive mill wastewater

\begin{abstract}
A B S T R A C T
Improving electricity generation from wastewater (DW) by using olive mill wastewater (OMW) was evaluated using single-chamber microbial fuel cells (MFC). Doing so single-chambers air cathode MFCs with platinum anode were fed with domestic wastewater (DW) alone and mixed with OMW at the ratio of 14:1 (w/w). MFCs fed with DW + OMW gave $0.38 \mathrm{~V}$ at $1 \mathrm{k} \Omega$, while power density from polarization curve was of $124.6 \mathrm{~mW} \mathrm{~m}^{-2}$. The process allowed a total reduction of TCOD and $\mathrm{BOD}_{5}$ of $60 \%$ and $69 \%$, respectively, recovering the $29 \%$ of the coulombic efficiency. The maximum voltage obtained from MFC fed with DW + OMW was 2.9 times higher than that of cell fed with DW. DNA-fingerprinting showed high bacterial diversity for both experiments and the presence on anodes of exoelectrogenic bacteria, such as Geobacter spp. Electrodes selected peculiar consortia and, in particular, anodes of both experiments showed a similar specialization of microbial communities independently by feeding used.
\end{abstract}

(c) 2013 Elsevier Ltd. All rights reserved.

\section{Introduction}

Oil reservoirs depletion and climate changes, are currently topics of major concern to explore renewable sources of energy, by developing sustainable and environment-friendly technologies. One of the main goal of research is the efficient use of biomasses, especially wastes from agricultural and municipal processes, that are, nowadays, mainly burnt, land-filled or accumulated as excess biomass representing an economic burden for communities and industries.

Conventional biological wastewater treatments, such as activated sludge processes are energy demanding because of aeration requirements (Logan, 2008); moreover they produce large

\footnotetext{
* Corresponding author. Tel.: +39 0250316544; fax: +39 0250316521.

E-mail address: fabrizio.adani@unimi.it (F. Adani).
}

amounts of residual solids (sludge) which are costly to be treated and disposed (Murray et al., 2008). Aiming at operational costs reduction and energy efficiency improvement, new biological processes have been recently developed and studied for energy production and wastewater reduction; these processes included: methanogenic anaerobic digestion, biological hydrogen production and ethanol fermentation (Pham et al., 2006).

Microbial fuel cells (MFCs) that belong to this categories, consist in a bio-electrochemical process that converts the chemical energy of biodegradable organic compounds into electricity by anaerobic oxidation. Responsible of the process are specific bacterial species, the so-called "exoelectrogens", mainly belonging to the gammaand delta-subgroups of Proteobacteria (e.g. Shewanella, Geobacter and Pseudomonas genera). These bacteria colonize the anode and produce electrons and protons from the organic matter, with $\mathrm{CO}_{2}$ and biomass as final products (Lovley, 2010). 
Several lab-scale studies were conducted to investigate power generation from artificial (Moon et al., 2006) or real wastewaters, such as vegetable wastes (Kannaiah Goud et al., 2011), brewery wastewater (Feng et al., 2008), cereal wastewater (Zuo et al., 2006), palm oil effluent (Cheng et al., 2010), paper wastewater (Nimje et al., 2012) and swine wastewater (Min et al., 2005). The power generated has been reported to be within the range of 40$300 \mathrm{~mW} \mathrm{~m}^{-2}$ depending on inoculum and substrate used, and reactor architecture. Power generated corresponded to a reduction of wastewater organic load, expressed as total chemical oxygen demand (TCOD), of 60-80\% (Liu et al., 2004).

Literature suggests that MFC could be a readily applicable technology, especially with industrial and agricultural wastewaters with a high content of easily degradable organic material, resulting in a net positive energy production. Domestic wastewater (DW) has been widely exploited in MFC to substitute conventional aerobic disposal treatment, that involves high capital expenditure, high sludge production to be disposed, and considerable operational and energy consumption costs. It has been reported, for example, the ability of MFC to generate $26 \mathrm{~mW} \mathrm{~m}^{-2}$ of power, removing the $80 \%$ of the TCOD from domestic wastewater (Liu et al., 2004).

Olive oil is one of the main agricultural products in the Mediterranean area, that contributes for $95 \%$ to the annual worldwide oil production (over 30 million $\mathrm{m}^{3}$ per year). The disposal of wastewaters coming from olive processing represents a huge environmental problem. This is particularly true for Italy that is one of the main olive oil producers in the world, with 1.2 million ha of land used for olive culture, yielding 3.2 $\mathrm{Mg} \mathrm{ha}^{-1}$ of oil (Source: EUROSTAT, 20042007). This means that about $2 \times 10^{6} \mathrm{~m}^{3}$ of olive mill wastewater (OMW) are produced annually in Italy, with a cost for their disposal of 30-50€ $\mathrm{m}^{-3}$ (ENEA, 2007).

According to olive fruit variety, cultivation conditions and extraction method used, OMW organic load (TCOD) may vary from 40 to $220 \mathrm{~g} \mathrm{~L}^{-1}$, with a polyphenols content ranging from 200 to $8000 \mathrm{mg} \mathrm{L}^{-1}$ (Azbar et al., 2004). Within this range polyphenols can potentially have inhibition effect on bacteria activity involved in OMW biological treatment (Ntaikou et al., 2009). As consequence of that, OMW disposal requires physicochemical treatment, such as coupled evaporation and combustion, chemical coagulation and sorption, and oxidation (Kestioglu et al., 2005), although microbiological treatments, such as anaerobic digestion have, also, been tested (Bertín et al., 2010).

OMW has been extensively studied to be treated by anaerobic digestion, alone or in co-digestion with other biomasses, to reduce COD and to produce energy (S1). Nevertheless all studies indicated that it was necessary to operate a wastewater dilution to eliminate microbial inhibition (Azbar et al., 2004). For example Azbar et al. (2004) by diluting OMW, removed the $85 \%$ of TCOD at $35^{\circ} \mathrm{C}$, with an organic load (TCOD) below $4 \mathrm{~g} \mathrm{~L}^{-1}$. Higher TCOD concentration than that indicated, or the use of undiluted OMW, inhibited the biological process (S1). Although studies cited indicated that diluted OMW can be anaerobically treated, no researches on the use of OMW by MFC are reported in the literature (Azbar et al., 2004). However OMW can be used to feed MFC by its dilution with other wastewater streams in order to reduce potential inhibition, allowing direct electricity production.

In this study it was investigated the effectiveness in using olive mill wastewater mixed with effluents coming from denitrification process of domestic wastewater (DW), in producing electricity in an optimized single-chamber open air cathode microbial fuel cell (scMFC). At the same time, the efficiency of the process in terms of TCOD and $\mathrm{BOD}_{5}$ removed, was tested. Bacterial populations selected in the microbial fuel cells were studied and microbial community coming from wastewater and wastewater plus olive wastewater were compared and discussed.

\section{Methods}

\subsection{Wastewater}

Domestic wastewater (DW) were collected from a wastewater treatment plant in Northern Italy. Olive mill wastewaters (OMW) were collected from Frantoio Confraternita Seconda, Contrada Breccelle (Isernia, Italy) using a three phase oil mill grinder. Samples were placed on ice, shipped overnight to the laboratory, and stored at $4{ }^{\circ} \mathrm{C}$; wastewaters were characterized upon arrival.

\subsection{MFC reactors: manufacture, configuration and operation}

Single-chamber, air-cathode MFCs containing graphite fiber brush anodes were constructed as previously described (Logan et al., 2007). Each reactor consisted of a liquid chamber $4 \mathrm{~cm}$ long by $5 \mathrm{~cm}$ in diameter, with a liquid volume of $28 \mathrm{~mL}$. Brush anodes were made of a core of two titanium wires with graphite fibers (PANEX33 $160 \mathrm{~K}$, ZOLTEK) cut to $2.5 \mathrm{~cm}$ in outer diameter and $2.5 \mathrm{~cm}$ long. Each brush had an estimated surface area of $0.22 \mathrm{~m}^{2}$ or $18,200 \mathrm{~m}^{2} \mathrm{~m}^{-3}$-brush volume for the brush, with $95 \%$ porosity (Logan et al., 2007).

The cathodes $\left(3.8 \mathrm{~cm}\right.$ diameter, $7 \mathrm{~cm}^{2}$ total exposed surface area) were made by applying a platinum catalyst $\left(0.4 \mathrm{mg} \mathrm{Ptcm}^{-2}\right.$, BASF) on the liquid-facing side of a $30 \mathrm{wt}$ \% wet-proofed carbon cloth (type B-1B, BASF, US), while four PTFE diffusion layers were added on the air-facing side (Cheng et al., 2006).

MFCs were firstly inoculated with a mixture $(60: 40 \mathrm{v} / \mathrm{v})$ of domestic wastewater (Canegrate Wastewater Treatment Plant, Italy) $(60: 40 \mathrm{v} / \mathrm{v})$ and buffer solution containing $1 \mathrm{~g} \mathrm{~L}^{-1}$ sodium acetate (PBS $100 \mathrm{mMol} \mathrm{L}^{-1} ; \mathrm{Na}_{2} \mathrm{HPO}_{4} 9.152 \mathrm{~g} \mathrm{~L}^{-1}, \mathrm{NaH}_{2} \mathrm{PO}_{4} \cdot \mathrm{H}_{2} \mathrm{O}$ $4.904 \mathrm{~g} \mathrm{~L}^{-1}, \mathrm{NH}_{4} \mathrm{Cl} 0.62 \mathrm{~g} \mathrm{~L}^{-1}, \mathrm{KCl} 0.26 \mathrm{~g} \mathrm{~L}^{-1} ; 982.5 \mathrm{~mL}$ PBS, trace minerals $12.5 \mathrm{~mL} \mathrm{~L}^{-1}$, vitamins $5 \mathrm{~mL} \mathrm{~L}^{-1}$ for each liter (Liu and Logan, 2004). The initial pH of the solution was $7.2 \pm 0.1$. When the maximum voltage output was similar for three consecutive cycles $(0.4 \pm 0.05)$, the buffer solution and the sodium acetate were gradually omitted, until only DW or OMW were fed into the cells.

The test was conducted as follow: the cells (in triplicate) were run simultaneously for three batch cycles for each feeding substrate, i.e. undiluted domestic wastewater, and a mixture of DW and OMW. The DW + OMW mixture ratio was $14: 1$, to create an appropriate feedstock for the MFC process (Logan et al., 2006 ) i.e., pH of $6.38 \pm 0.06$ and the organic load of $4.3 \pm 0.4 \mathrm{~kg}$ TCOD $\mathrm{m}^{-3}$. Feeding solutions were replaced when the voltage dropped below $40 \mathrm{mV}$, forming one complete cycle of operation. All the tests were performed at room temperature $\left(23 \pm 3^{\circ} \mathrm{C}\right)$.

\subsection{Measurements and chemical analyses}

The cathodes and anodes were connected with titanium wire and the voltage was measured by an external resistor $\left(R_{\mathrm{ex}}=1 \mathrm{k} \Omega\right)$ every 15 min using a multimeter (2700; Keithley, United States) connected to a personal computer. Current generation was calculated by using the $I=E / R$ equation, while power output of the cells by using the $P=I * E$ equation, where $I(\mathrm{~A})$ is the current, $E(\mathrm{~V})$ the voltage, $R(\Omega)$ the external resistance and $P(\mathrm{~W})$ the power. Coulombic efficiency $(\mathrm{CE})$, the ratio between Coulombs recovered and total Coulombs in the substrate, was calculated as previously described (Logan et al., 2006).

Polarization curves were obtained by varying the external resistance (10-10,000 $\Omega$ ) every $30 \mathrm{~min}$. and measuring the cell voltage.

Power density $\left(\mathrm{mW} \mathrm{m}^{-2}\right)$ and current density $\left(\mathrm{mA} \mathrm{m}^{2}\right)$ were based on the surface area of one side of the cathode $\left(7 \mathrm{~cm}^{2}\right)$ in 
agreement with previous studies and findings indicating that cathode (rather than the anode) limits power production in this reactor (Logan et al., 2006).

Total chemical oxygen demand (TCOD), biological oxygen demand $\left(\mathrm{BOD}_{5}\right)$ total nitrogen $(\mathrm{TN})$ and ammonia nitrogen $\left(\mathrm{N}-\mathrm{NH}_{4}{ }^{+}\right.$) were measured according to Standard Methods (APHA, AWWA, WPCF, 1998). $\mathrm{pH}$ and conductivity were measured using $\mathrm{pH}$ meter and conductivity meter (PC 2700, Eutech Instruments, Netherlands). Concentrations of volatile fatty acids (VFA) (acetate, propionate, butyrate) were measured by high performance liquid chromatograph (Binary HPLC pump, Waters 1525, United States) equipped with an ultraviolet detector (Waters 2487, dual $\lambda$ absorbance detector, United States) and a $300 \mathrm{~m} \times 7.8 \mathrm{~mm}$ Aminex HPX-97H column. The samples were filtered by a $0.2 \mu \mathrm{m}$ syringe membrane (Sartorius Minisart ${ }^{\circledR}$ ) before analysis. Sulfuric acid $\left(0.0025 \mathrm{~mol} \mathrm{~L}^{-1}\right)$ was used as a mobile phase at a flow rate of $0.6 \mathrm{~mL} \mathrm{~min}^{-1}$.

\subsection{Microbial analyses}

\subsubsection{DNA extraction}

Microbial cells were separated from MFC liquid phase by centrifugation (15 min at $3200 \mathrm{rpm}$ and room temperature). Biomass samples were taken at the end of the final cycle of each experimentation from anode by cutting a portion of graphite fibers using flame-sterilized scissors and from cathode by scraping off biomass from the carbon cloth with a sterile spatula. Collected biomass was then suspended in sterile saline solution $\left(\mathrm{NaCl} 9 \mathrm{~g} \mathrm{~L}^{-1}\right)$ and cells were separated by centrifugation. Graphite fibers and cell pellets resulting from centrifugation were stored at $-20^{\circ} \mathrm{C}$ until DNA extraction, which was performed using the PowerSoil DNA Isolation kit (Mo-Bio Laboratories) according to the manufacturer's instructions. DNA extracts were quantified by gel electrophoresis and used for subsequent molecular analysis of the total bacterial community.

\subsubsection{PCR-denaturing gradient gel electrophoresis (DGGE) analysis and statistical analyses}

Bacterial 16S rRNA gene was amplified by PCR using primers 357-F (CCTACGGGAGGCAGCAG), added to the 5' end of a 40-bp GC clamp, and 907-R (CCGTCAATTCCTTTGAGTTT). PCR reactions and thermal protocols were performed as previously described (Merlino et al., 2012). PCR products (approx. $100 \mathrm{ng}$ ) were loaded onto $7 \%(\mathrm{w} / \mathrm{v})$ polyacrylamide gels $(0.75 \mathrm{~mm}$ thick) containing a gradient of $40-60 \%$ denaturant (considering $100 \%$ denaturant $7 \mathrm{M}$ urea and $40 \%$ formamide). Electrophoresis was run in $1 \times$ TAE buffer using a D-Code Universal Mutation Detection System (BioRad) at $90 \mathrm{~V}$ and $60^{\circ} \mathrm{C}$ for $17 \mathrm{~h}$. Gels were stained with SYBR(R) Green I Nucleic A (Invitrogen) and documented with the GelDoc 2000 apparatus (BioRad) by using the Diversity Database software (BioRad). Each DGGE gel lane was converted into a binary matrix using the free software Imagejversion 1.44o (Rasband, 1997-2012). The matrices resulting from the conversion of the lanes were statistically analyzed by Principal Component Analysis (PCA) using the program XLSTAT version 7.5.2 (Addinsoft, France) on autoscaled data.

Relevant DNA bands were excised from DGGE gels with sterile scalpel and eluted in $50 \mu \mathrm{l}$ of Tris- $\mathrm{HCl} 10 \mathrm{mM} \mathrm{pH}$ 8. Ten microliters of the eluted DNA were used as template for PCR re-amplification with the same primer-set of the first amplification, excluding the GC clamp for primer 357-F. PCR products of re-amplification reaction were sequenced (Macrogen). The sequences were compared against the NCBI genomic database through the BLAST search alignment tool. Phylogenetic analyses were conducted using MEGA version 5 (Tamura et al., 2011).
The nucleotide sequences reported in this paper have been deposited to the European Nucleotide Archive under the accession numbers HG423152-HG423164.

\section{Results and discussion}

\subsection{Power production}

After an acclimation period of $600 \mathrm{~h}$ (data not shown) voltage generation cycles were obtained for each MFC, as previously described. Three MFCs were filled with only domestic wastewater (DW) and voltage was measured for three cycles (300 h of operation time). During the first and the second cycle low voltage values $(<0.1 \mathrm{~V})$ were measured: the maximum voltage $(0.13 \mathrm{~V})$ was obtained at the end of the third cycle (Fig. 1). Power density and current density, gained from polarization curve (Fig. 2), were of $17.6 \mathrm{~mW} \mathrm{~m}^{-2}\left(112 \mathrm{~mA} \mathrm{~m}^{-2}\right)$ (external resistance of $2 \mathrm{k} \Omega$ ) and of $227 \mathrm{~mA} \mathrm{~m}^{-2}$ (external resistance of $10 \Omega$ ), respectively.

At the same time, three additional MFCs were filled with oil mill wastewater (OMW) mixed with DW as previously described. This mixture was used to generate three voltage cycles $(\approx 1000 \mathrm{~h}$ operation time). In this case the maximum voltage $(0.38 \mathrm{~V})$ was obtained just at the first cycle and the same value was reached in subsequent cycles (Fig. 1). Polarization curve shows a power density of $124.6 \mathrm{~mW} \mathrm{~m}^{-2}$ (596.6 $\mathrm{mA} \mathrm{m}^{-2}$ ) (external resistance of $500 \Omega$ ) and a current density of $949.5 \mathrm{~mA} \mathrm{~m}^{-2}$ (external resistance of $10 \Omega$ ) (Fig. 2).

A third series of three MFCs were filled with only OMW; in this case, low voltage was generated and no TCOD was removed (data not shown). Volumetric power density (Pv), obtained as previously described, was calculated from the polarization curves and from the maximum voltage peak $\left(P V_{\max }\right)$. Domestic wastewater gave a maximum volumetric power of $0.33 \mathrm{Wm}^{-3}(\mathrm{PV} ; 1 \mathrm{k} \Omega)$ and $0.66 \mathrm{Wm}^{-3}\left(\mathrm{PV}_{\max } ; 1 \mathrm{k} \Omega\right)$ for $\mathrm{DW}$; otherwise $\mathrm{OMW}+\mathrm{DW}$ gave $3.2 \mathrm{Wm}^{-3}(\mathrm{PV} ; 1 \mathrm{k} \Omega)$ and $5.17 \mathrm{Wm}^{-3}\left(\mathrm{PV}_{\max } ; 1 \mathrm{k} \Omega\right)$.

OMW is not ordinarily used in MFCs so that the electricity production acquired in this work, cannot be compared with similar literature data; however results obtained can be compared with those obtained using other agricultural wastes tested by using a single chamber air cathode MFC. In particular from the Table 1, that reports results obtained using swine wastewater, corn stover and brewery wastewater (Min et al., 2005; Zuo et al., 2006; Feng et al., 2008). It can be seen that different biomasses gave a great variability in the organic load (influent) influencing MFCs performances. Nevertheless, organic load used in this work was within the range reported, allowing a first comparison with the literature. Power density obtained using OMW + DW was of $124.6 \mathrm{~mW} \mathrm{~m}^{-2}$ (external resistance of $500 \Omega$ ) that was lower than those obtained by Feng et al. (2008), i.e. $205 \mathrm{~mW} \mathrm{~m}^{-2}$ (external resistance of $1 \mathrm{k} \Omega$ ), Zuo et al. (2006), i.e. $371 \mathrm{~mW} \mathrm{~m}^{-2}$ (external resistance of $250 \Omega$ ), and Min et al. (2005), i.e. $261 \mathrm{~mW} \mathrm{~m}^{-2}$ (external resistance of $200 \Omega$ ). This result can be justified taking into account both the absence of buffer solution during the experiment and the use of lower temperature $\left(23^{\circ} \mathrm{C}\right)$ than that used in the cited works $\left(30^{\circ} \mathrm{C}\right)$. On the other hand data obtained was better than that reported by Nimje et al. (2012) (Table 1) that using food/dairy wastewaters and adopting similar experimental conditions of this work, reported a power density of only $0.13 \mathrm{~mW} \mathrm{~m}^{-2}$ (external resistance of $680 \Omega$ ).

\subsection{Chemical analysis and coulombic efficiency}

Chemical characterizations were conducted on all wastewaters treated, considering both feeding (input) and effluent (output) streams of MFCs (Table 2). 

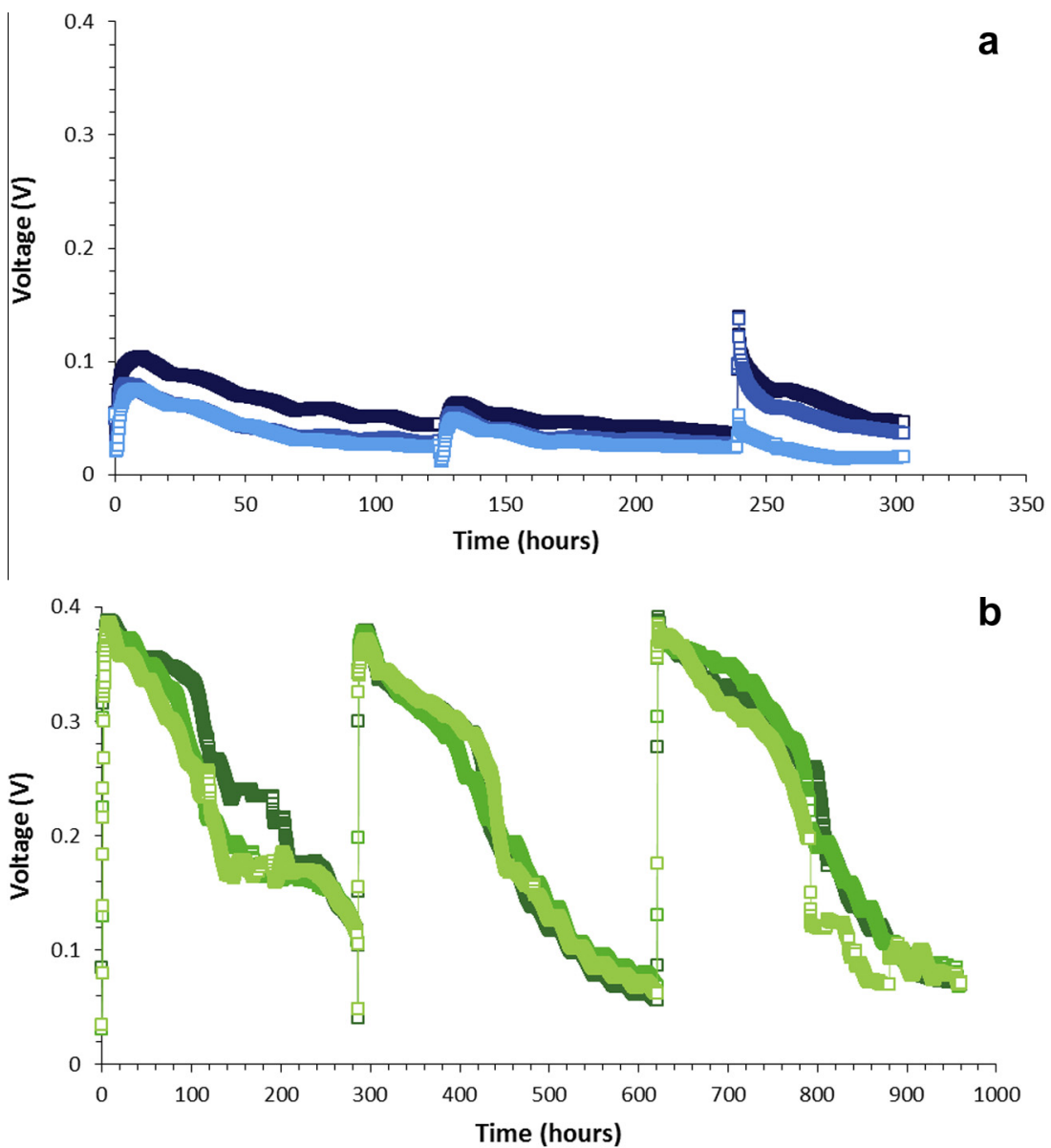

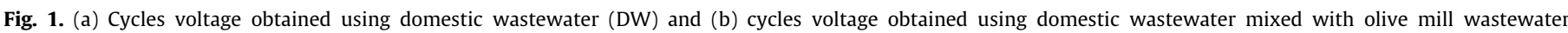
$(\mathrm{DW}+\mathrm{OMW})$.

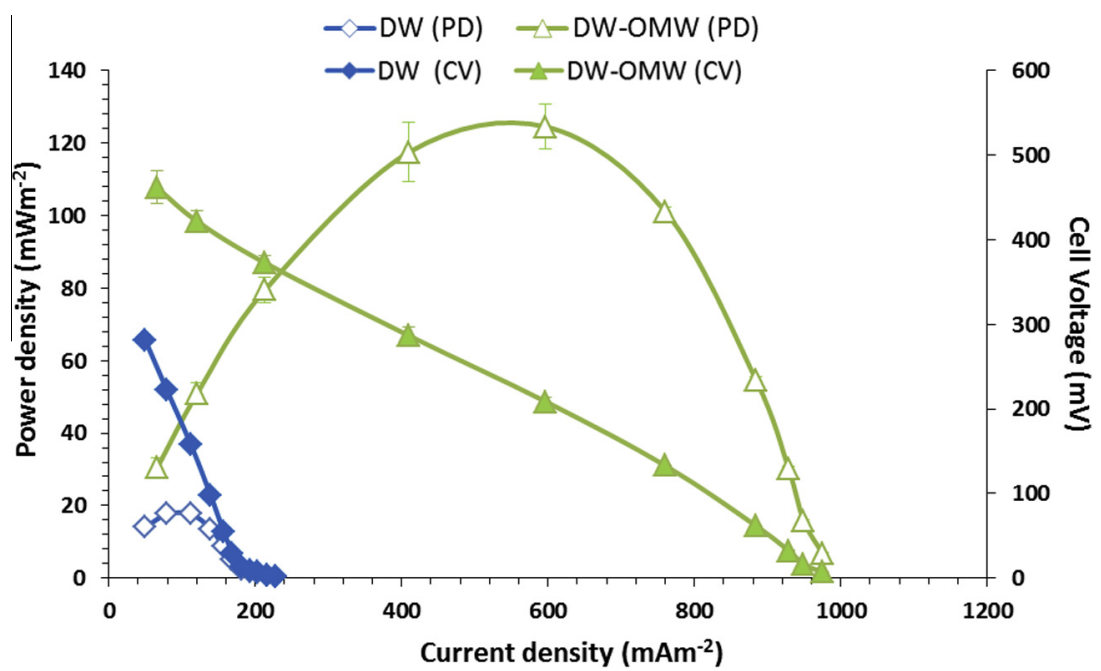

Fig. 2. Polarization curves obtained from both substrates studied in this work (CV = Cell voltage; $P D=$ Power density $)$.

About $40-60 \%$ of TCOD and $\mathrm{BOD}_{5}$ of input wastewater was removed in all conditions tested. In particular, when DW + OMW was used as substrate TCOD was reduced of more than $60 \%$ although it showed a starting TCOD much higher (of 153\%) than that of DW (Table 2). Again $\mathrm{BOD}_{5}$ of the mix, that was higher (of 200\%) than that of DW (Table 2), was reduced more (total reduction of $70 \%$ ) than that of DW (total reduction of $48 \%$ ). These results indicated that the organic carbon introduced with OMW was readily biodegradable such as suggested by $\mathrm{BOD}_{5} / \mathrm{TCOD}$ ratio of 0.57 to be compared with that of $\mathrm{DW}$, i.e. $\mathrm{BOD}_{5} / \mathrm{COD}=0.44$. The TCOD biodegradability was due, above all, to the high presence of VFAs, that well represented olive wastewater (Table 2). Nevertheless, these data, alone, cannot explained the fact that despite the increase of TCOD from $2.6 \mathrm{~kg} \mathrm{~m}^{-3}$ to $4 \mathrm{~kg} \mathrm{~m}^{-3}$ (+153\%) (Table 2) 
Table 1

Power production obtained in this work compared with others studies.

\begin{tabular}{|c|c|c|c|c|c|c|c|c|c|}
\hline & $\mathrm{mV}(\Omega)$ & $\mathrm{OCV}(\mathrm{mV})$ & $\begin{array}{l}\text { Cur. den. } \\
\left(\mathrm{mA} \mathrm{m}^{-2}\right)(\Omega)\end{array}$ & $\begin{array}{l}\text { Pow. den. } \\
\left(\mathrm{mW} \mathrm{m}^{-2}\right)(\Omega)\end{array}$ & C.E. & COD removal & O.L. ${ }^{\mathrm{a}}\left(\mathrm{COD} \mathrm{ml} \mathrm{g}^{-1}\right)$ & $\mathrm{pH}$ input & Ref. \\
\hline Brewery WW & $628(500)$ & 1 & 0.76 (1 k) & 205 (1 k) & $10 \%$ & $87 \%$ & $2250 \pm 418$ & 6.5 & Feng et al. 2008 \\
\hline Corn stover & 1 & 1 & $1446(250)$ & $371(250)$ & $19.3-29.5 \%$ & $60-70 \%$ & $250-1000$ & 1 & Zuo et al. 2006 \\
\hline Swine WW & 357 (1 k) & 1 & $1.4(200)$ & $261(200)$ & $8 \%$ & $27 \%$ & $8320 \pm 190$ & 1 & Min et al. 2005 \\
\hline Food/Dairy WW & $600(1 \mathrm{k})$ & 647 & 1 & $0.13(680)$ & $2.5 \%$ & $77 \%$ & $1562 \pm 20$ & 5.3 & Nimje et al. 2012 \\
\hline$(\mathrm{OMW}+\mathrm{DW})$ & $380(1 \mathrm{k})$ & 0.2 & $596.6(500)$ & $124.6(500)$ & $29 \%$ & $60 \%$ & $4000 \pm 410$ & 6.4 & This work \\
\hline
\end{tabular}

a O.L., Organic load.

Table 2

Chemical characterization of wastewaters used as substrates in this work.

\begin{tabular}{|c|c|c|c|c|c|}
\hline \multirow[t]{2}{*}{ Parameters } & \multirow{2}{*}{$\begin{array}{l}\text { OMW } \\
\text { Input }\end{array}$} & \multicolumn{2}{|l|}{ DW } & \multicolumn{2}{|l|}{ DW + OMW } \\
\hline & & Input & Output & Input & Output \\
\hline $\mathrm{pH}$ & $4.9 \pm 0.1$ & $7.1 \pm 0.02$ & $6.6 \pm 0.05$ & $6.4 \pm 0.06$ & $6.9 \pm 0.3$ \\
\hline Conductivity $\left(\mu \mathrm{S} \mathrm{cm}^{-1}\right)$ & $9165 \pm 27$ & $1051 \pm 77$ & $792 \pm 33$ & $1790 \pm 0.1$ & $1230 \pm 0.1$ \\
\hline $\operatorname{TCOD}\left(\mathrm{kg} \mathrm{m}^{-3}\right)$ & $28.4 \pm 1.2$ & $2.6 \pm 0.3$ & $1.5 \pm 0.1$ & $4 \pm 0.4$ & $1.6 \pm 0.1$ \\
\hline $\mathrm{BOD}_{5}\left(\mathrm{~g} \mathrm{~L}^{-1}\right)$ & $15.3 \pm 1.6$ & $1.15 \pm 0.2$ & $0.6 \pm 0.05$ & $2.3 \pm 0.4$ & $0.7 \pm 0.1$ \\
\hline Total Nitrogen $\left(\mathrm{mg} \mathrm{L}^{-1}\right)$ & $384 \pm 14$ & $126.7 \pm 3.1$ & $78.6 \pm 14.5$ & $152.8 \pm 8$ & $105 \pm 2.7$ \\
\hline Ammonia Nitrogen $\left(\mathrm{mg} \mathrm{L}^{-1}\right)$ & $14 \pm 0.2$ & $54.3 \pm 5.5$ & $4.1 \pm 0.1$ & $47.0 \pm 17.1$ & $3.15 \pm 0.3$ \\
\hline Phenols ( $\mathrm{mg} \mathrm{L}^{-1}$ ) & $1529 \pm 21$ & u.d.l & u.d.l & $106 \pm 5$ & u.d.l \\
\hline \multicolumn{6}{|l|}{ Volatile fatty acids ( $\left.m g L^{-1}\right)$} \\
\hline Acetate & $4114 \pm 60$ & $60 \pm 7$ & u.d.l. & $361 \pm 13$ & $194 \pm 34$ \\
\hline Propionate & $1679 \pm 11$ & u.d.l & u.d.l. & $69 \pm 2.5$ & u.d.l \\
\hline Butyrate & $1849 \pm 12$ & u.d.l & u.d.l. & $45 \pm 1.5$ & u.d.l \\
\hline Isobutyrate & u.d. $\mathrm{l}^{\mathrm{a}}$ & u.d.l & u.d.l. & $82 \pm 2.7$ & u.d.l \\
\hline Total volatile fatty acids $\left(\mathrm{mg} \mathrm{L}^{-1}\right)$ & $5300 \pm 103$ & $65 \pm 2$ & u.d.l. & $560 \pm 31$ & $207 \pm 16$ \\
\hline Total alkalinity $\left(\mathrm{mg} \mathrm{L}^{-1}\right)$ & $4800 \pm 79$ & $500 \pm 20$ & u.d.l. & $833 \pm 36$ & $393 \pm 53$ \\
\hline
\end{tabular}

a u.d.l., under detection limit.

after the addition of OMW to DW, the final TCODs were very similar for both wastewaters studied $\left(1.5\right.$ and $1.6 \mathrm{~kg} \mathrm{~m}^{-3}$ for DW and OMW + DW, respectively) (Table 2). Probably the use of the mix allowed a more efficacy in TCOD degradation of both wastewater. This fact has not yet found reasonable explanation (Table 2) as (see next chapter) non differences in microbial community were observed in the liquid phases. Nevertheless OMW seems to be the driving factor in the selection on the anode of MFC of a more efficient exoelectrogen bacterial consortium that by optimizing electron transfer could improve degradation performance of the entire system (see next chapter).

TCOD degradability explained different MFCs performance: Coulombic efficiency (CE) calculated for DW and DW + OMW were of $3 \%$ and $29 \%$, respectively (Table 1 ). Therefore the addition of OMW to DW resulted in an 10-fold increase of $\mathrm{CE}$, without altering final TCOD.

\subsection{Microbial communities}

Biomass from the electrodes and liquid phase was collected at the end of the experiments performed with fuel cells fed with both DW and DW + OW. A molecular microbial ecology approach, independent from cultivation, was explored to describe the phylogenetic diversity of the bacterial communities selected at the end of each experiments in the circulating phase and growing as a biofilm on the electrodes. Anodic communities were particularly interesting, since they were putatively composed by exoelectrogenic bacterial species able to directly transfer electrons to the electrode. Analysis of the cathode biofilm composition was also carried out, since it is considered a critical aspect of MFC design and performance (Kiely et al., 2011).

Total genomic DNA was isolated from all samples and a comparison of the bacterial communities was carried out through 16S rRNA-DGGE fingerprinting. Molecular analysis, generated characteristic community patterns (Fig. 3a) in which each poly- morphic band putatively corresponded to a different bacterial taxon present in the sample. Statistical analyses of DGGE profiles was then used to describe the structure of the microbial communities, assuming that the relative proportions of the different species can be estimated from the relative intensity of the bands (Beecroft et al., 2012).

The obtained fingerprints showed that all the analyzed samples contained a bacterial community rich in phylogenetic diversity. Comparing the two different experimental trials that used DW and OMW + DW as substrate, it can be seen that the microbial consortia of both anode and cathode of DW trial, showed a slight reduction of the biodiversity with less dominating bands than OMW + DW trials (Fig. 3a). DGGE fingerprinting revealed that on the electrodes of both experiments there was an enrichment of peculiar bacterial populations that were under the detection limit in the liquid phase (Fig. 3a).

Principal Component Analysis (PCA) of the DGGE profiles (Fig. 3b) confirmed that liquid phase, anode and cathode harbored different bacterial communities and confirmed that the electrodes selected peculiar bacterial assemblages, different from the planktonic cells present in the feeding mixture (Fig. 3b). A strong divergence in the communities developed on the cathodes of DW and OMW + DW experiments was observed (Fig. 3b, cluster A), while there was a high convergence of the microbial communities selected at the anodes at the end of both trials (Fig. 3 b, cluster C), independently from the MFC feeding mixture (S1; Yates et al., 2012). This fact suggested that in both the experiments there was a positive enrichment of exoelectrogen bacterial species responsible for the production of electricity. On the contrary, bacterial communities of the liquid phase showed high similarity in the different experiments (Fig. 3b, cluster B), indicating that the addition of OMW to the MFC feeding, did not significantly affected the composition of the bacterial planktonic community. This results was expected, since the mix used for OMW + DW trial had a predominant proportion of domestic wastewater (15:1 ratio). 

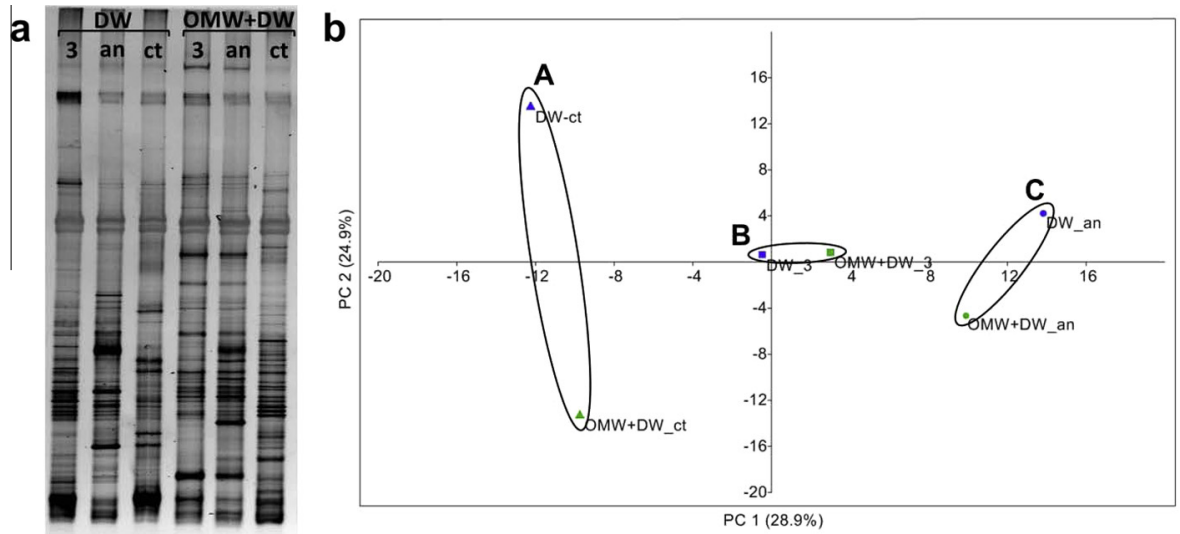

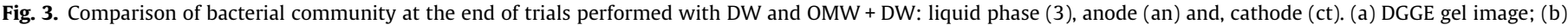
Principal Component Analysis carried out on DGGE profiles.

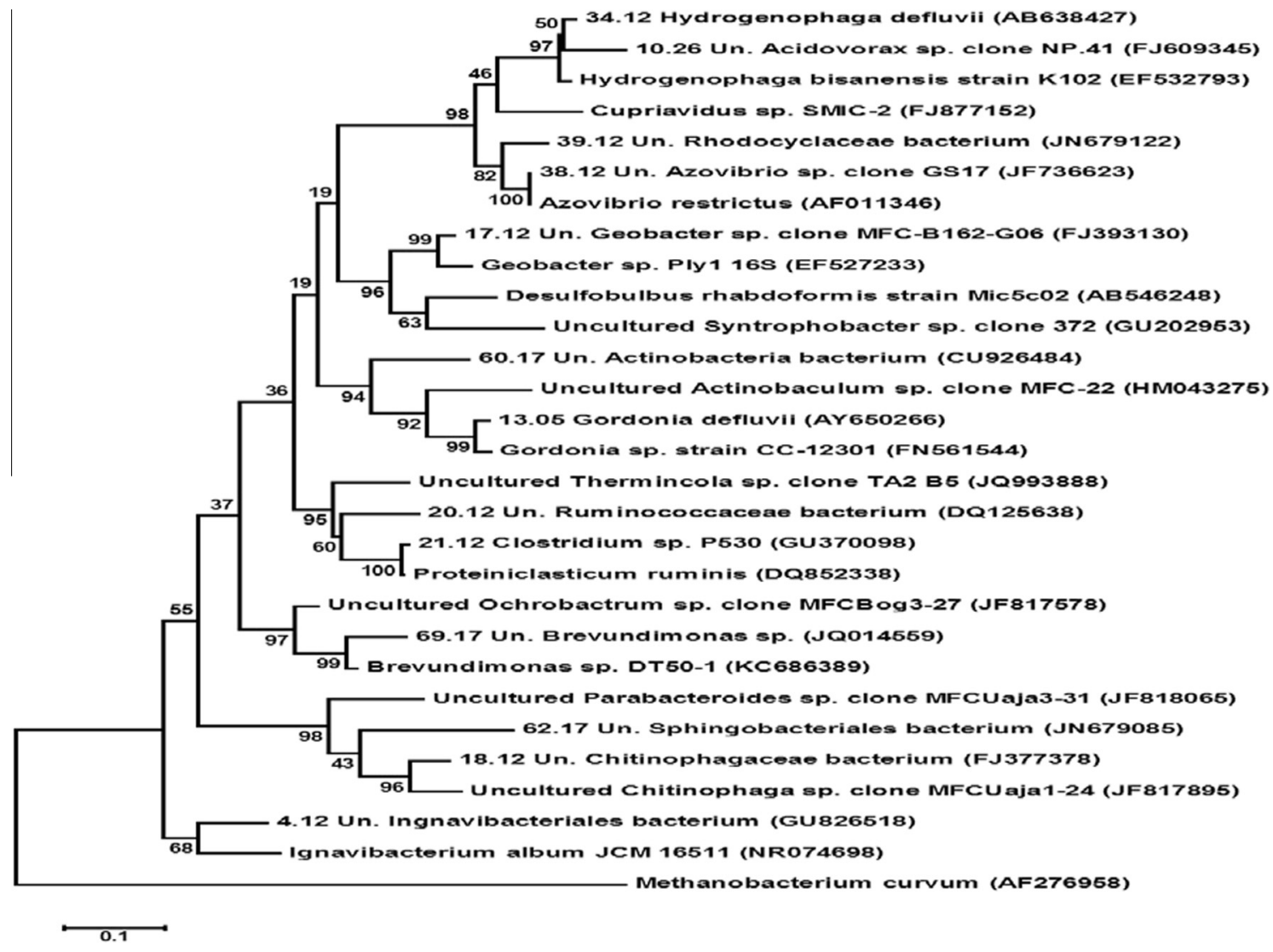

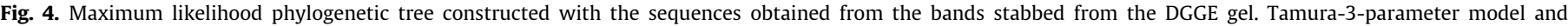

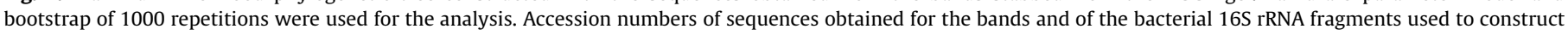
the tree are shown in parentheses.

However, the high energy produced by the MFCs fed with OMW + DW suggested that the OMW constituted a driving factor in the selection on the anode of a more efficient exoelectrogen bacterial consortium.

Sequences obtained from bands excised from the gel were mainly affiliated to the phyla Proteobacteria, Firmicutes, Bacteroidetes and Actinobacteria (Fig. 4). These results confirmed the wide biodiversity of all samples and were in agreement with previous studies (Ishii et al., 2012). Representatives of $\beta$-Proteobacteria affiliated to (i) Hydrogenophaga defluvii and Acidovorax sp., belonging to Comamonadaceae family and (ii) Azovibrio sp., belonging to Rhodocyclaceae family were identified in both anode and cathode biofilms. The $\beta$ - subgroup of the Proteobacteria comprises several aerobic or facultative aerobic bacteria highly versatile in their degradation capacities. Their presence was possible because of oxygen intrusion from the cathode to the anode, which might support aerobic growth, and could be related to organic matter degradation processes. Bacterial species that developed on the anodes included well known exoelectrogenic bacteria, such as Geobacter sp., that is considered in cells fed with acetate and volatile fatty acids (VFA) responsible for the direct electron transfer to MFC anode (Freguia et al., 2010). However, no evidence was observed for the presence of $\gamma$-Proteobacteria, widely found in other microbial fuel cells using different inocula 
sources (S1) and to which belong known electrogenic microbes such as Shewanella sp. (S1).

Bacteria belonging to the phylum Firmicutes (order Clostriadiales) and represented by Clostridium sp. and Ruminoccocaeae bacterium, were present among the electrode bacterial communities. In many studies bacteria belonging to this phylum were found to be an important part of the bacterial anodic community (S1) and their role in electron exocellular transfer was previously proven (Rabaey et al., 2004).

Bacteria belonging to the phylum Bacteroidetes, in particular to Chitinophagaceae family and Sphingobacterales order, were, also, identified in the anodic community. Different representative of this phylum have been previously found in a number of studies carried out with different technological solutions and substrates, demonstrating their role in organic matter degradation and/or current production. Although the ecological roles of these organisms in the anaerobic systems is not yet clear, they were considered to ferment small carbohydrates and amino acids contributing to organic matter degradation (Sekiguchi et al., 1998). Bacteroidetes were identified by Sekiguchi et al. (1998) in a two-chamber MFC fed with cellulose with graphite fibers anode. Beecroft et al. (2012), moreover, found Bacteroidetes in a single-chamber MFC with carbon fibers as anode fed with a synthetic medium composed mainly of sucrose that acted both as carbon and as electron source.

Gordonia defluvii and other unidentified uncultured species all belonging to the phylum Actinobacteria were, also, identified in the anode bacterial community. The presence of bacteria affiliated to this group can be explained with the necessity, inside to the microbial community, of different metabolic capabilities to degrade complex substrates in smaller compounds, to be used as electron donor to the anode by electrochemically active bacteria (Zhang et al., 2012). Other species with a not yet explained role were, also, identified in the electrode bacterial biofilm, such as Chlorobi belonging to the Ingnavibacteriales order, and previously described by Zhang et al. (2011) in MFCs conducted at neutral$\mathrm{pH}$ conditions.

Result obtained revealed the presence of exoeletrogenic bacteria on the anode surface when using both substrates; that means that OMW did not influence bacteria growth. This could be explained taking into consideration the dilution of OMW with DW (14 times) reducing phenols content and so inhibitory activity, i.e. phenol contents under the inhibitory concentration (Azbar et al., 2004) (Table 2) that is.

\section{Conclusions}

Improving electricity generation from wastewater by using olive mill wastewater (OMW) treatment was evaluated using single-chamber microbial fuel cells. Although OMW was not considered a good substrate for microbiological process, power generation $\left(124.6 \mathrm{~mW} \mathrm{~m}^{-2}\right.$ ) and total oxygen demand reduction (65\%) evidenced how OMW mixed with domestic wastewater, could be suitable in this unconventional treatment process. Microbial analysis showed the presence of exoelectrogenic bacteria (Geobacter sp.) on the anodes in agreement with previous studies. In conclusion this work indicated that MFC is suitable approach for the biological treatment of diluted OMW wastewaters.

\section{Acknowledgements}

The authors thank Ms C. D'Ottavi for her technical support. The financial support of the Italian Ministry for Environment (MATTM, Project MECH2) and of the Ager Consortium is gratefully acknowledged. Partially supported by "Progetto AGER", grant no. 20110283.

\section{Appendix A. Supplementary data}

Supplementary data associated with this article can be found, in the online version, at http://dx.doi.org/10.1016/j.biortech.2013. 08.033 .

\section{References}

APHA, AWWA, WPCF, 1998. Standard Methods for the Examination of Water and Wastewater, 20th ed. American Public Health Association, Washington, DC.

Azbar, N., Bayram, A., Filibeli, A., Muezzinoglu, A., Sengul, F., Ozer, A., 2004. A review of waste management options in olive oil production. Crit. Rev. Env. Sci. Tec. 34 209-247.

Beecroft, N.J., Zhao, F., Varcoe, J.R., Slade, R.C.T., Thumser, A.E., Avignone-Rosa, C., 2012. Dynamic changes in the microbial community composition in microbial fuel cells fed with sucrose. Appl. Microbiol. Biotechnol. 93, 423-437.

Bertín, L., Lampis, S., Todaro, D., Scoma, A., Vallini, G., Marchetti, L., Majone, M., Fava F., 2010. Anaerobic acidogenic digestion of olive mill wastewaters in biofilm reactors packed with ceramic filters or granular activated carbon. Water Res. 44 , 4537-4549.

Cheng, S., Liu, H., Logan, B.E., 2006. Increased performance of single-chamber microbial fuel cells using an improved cathode structure. Electrochem. Commun. 8, 489-494.

Cheng, J., Zhu, X., Ni, J., Borthwick, A., 2010. Palm oil mill effluent treatment using a two-stage microbial fuel cells system integrated with immobilized biological aerated filters. Bioresour. Technol. 101, 2729-2734.

ENEA, 23 ottobre 2007. Workshop "Acque di vegetazione olearie: trattamento e valorizzazione nel rispetto dell'ambiente".

EUROSTAT, 2004-2007. Cronos Media.

Feng, Y., Wang, X., Logan, B.E., Lee, H., 2008. Brewery wastewater treatment using air-cathode microbial fuel cells. Appl. Microbiol. Biot. 78 (5), 873-880.

Freguia, S., Teh, E.H., Boon, N., Leung, K.M., Keller, J., Rabaey, K., 2010. Microbial fuel cells operating on mixed fatty acids. Bioresour. Technol. 101, 1233-1238.

Ishii, S., Suzuki, S., Norden-Krichmar, T.M., Nealson, K.H., Sekiguchi, Y., Gorby, Y.A., Bretschger, O., 2012. Functionally stable and phylogenetically diverse microbial enrichments from microbial fuel cells during wastewater treatment. PLoS One 7, e30495.

Kannaiah Goud, R., Suresh, Babu.P., Venkata Mohan, S., 2011. Canteen based composite food waste as potential anodic fuel for bioelectricity generation in single chambered microbial fuel cell (MFC): bio-electrochemical evaluation under increasing substrate loading condition. Int. J. Hydrogen Energy 36 (10), 6210-6218.

Kestioglu, K., Yonar, T., Azbar, N., 2005. Feasibility of physico-chemical treatment and advanced oxidation processes (AOPs) as a means of pretreatment of olive mill effluent OME. Process Biochem. 40, 2409-2416.

Kiely, P.D., Rader, G.K., Regan, J.M., Logan, B.E., 2011. Long-term cathode performance and the microbial communities that develop in microbial fuel cells fed different fermentation endproducts. Bioresour. Technol. 102, 361366.

Liu, H., Logan, B.E., 2004. Electricity generation using an air cathode single chamber microbial fuel cell in the presence and absence of a proton exchange membrane. Environ. Sci. Technol. 38, 4040-4046.

Liu, H., Ramnarayanan, R., Logan, B.E., 2004. Production of electricity during wastewater treatment using a single chamber microbial fuel cell. Environ. Sci. Technol. 38, 2281-2285.

Logan, B.E., 2008. Microbial Fuel Cells. Wiley, New York.

Logan, B.E., Aelterman, P., Hamelers, B., Rozendal, R., Schröeder, U., Keller, J. Freguiac, S., Verstraete, W., Rabaey, K., 2006. Microbial fuel cells: methodology and technology. Environ. Sci. Technol. 40, 5181-5192.

Logan, B.E., Cheng, S., Watson, V., Estadt, G., 2007. Graphite fiber brush anodes for increased power production in air-cathode microbial fuel cells. Environ. Sci. Technol. 41, 3341-3346.

Lovley, D.R., 2010. The microbe electric: conversion of organic matter to electricity. Curr. Opin. Biotechnol. 19, 564-571.

Merlino, G., Rizzi, A., Villa, F., Sorlini, C., Brambilla, C., Navarotto, P., Bertazzoni, B. Zagni, M., Araldi, F., Daffonchio, D., 2012. Shifts of microbial community structure during anaerobic digestion of agro-industrial energetic crops and food industry byproducts. J. Chem. Technol. Biotechnol. 87, 1302-1311.

Min, B., Kim, J.R., Oh, S.E., Regan, J.M., Logan, B.E., 2005. Electricity generation from swine wastewater using microbial fuel cells. Water Res. 39, 4961-4968.

Moon, H., Chang, I.S., Kim, B.H., 2006. Continuous electricity production from artificial wastewater using a mediator-less microbial fuel cell. Bioresour. Technol. 97, 621-627.

Murray, A., Horvath, A., Nelson, K.L., 2008. Hybrid life-cycle environmental and cost inventory of sewage sludge treatment and end-use scenarios: a case study from China. Environ. Sci. Technol. 42, 3163-3169.

Nimje, V.R., Chen, C.-Y., Chen, H.-R., Chen, C.-C., Huang, Y.M., Tseng, M.-J., Cheng, K.C., Chang, Y.-F., 2012. Comparative bioelectricity production from various wastewaters in microbial fuel cells using mixed cultures and a pure strain of Shewanella oneidensis. Bioresour. Technol. 104, 315-323.

Ntaikou, I., Kourmentza, C., Koutrouli, E.C., Stamatelatou, K., Zampraka, A Kornaros, M., Lyberatos, G., 2009. Exploitation of olive oil mill wastewate for combined biohydrogen and biopolymers production. Bioresour. Technol. 100, 3724-3730. 
Pham, T.H., Rabaey, K., Aelterman, P., Clauwaert, P., De Schamphelaire, L., Boon, N. Verstraete, W., 2006. Microbial fuel cells in relation to conventional anaerobic digestion technology. Eng. Life Sci. 6, 285-292.

Rabaey, K., Boon, N., Siciliano, S.D., Verhaege, M., Verstraete, W., 2004. Biofuel cells select for microbial consortia that self-mediate electron transfer. Appl. Environ. Microbiol. 70, 5373-5382.

Rasband, W.S., 1997-2012. ImageJ, U.S. National Institutes of Health, Bethesda Maryland, USA. Available from: <http://imagej.nih.gov/ij/>.

Sekiguchi, Y., Kamagata, Y., Syutsubo, K., Ohashi, A., Harada, H., Nakamura, K., 1998. Phylogenetic diversity of mesophilic and thermophilic granular sludges determined by 16S rRNA gene analysis. Microbiology 144, 2655-2665.

Tamura, K., Peterson, D., Peterson, N., Stecher, G., Nei, M., Kumar, S., 2011. MEGA5 molecular evolutionary genetics analysis using maximum likelihood, evolutionary distance, and maximum parsimony methods. Mol. Biol. Evol. 28, 2731-2739.

Yates, M.D., Kiely, P.D., Call, D.F., Rismani-Yazdi, H., Bibby, K., Peccia, J., Regan, J.M., Logan, B.E., 2012. Convergent development of anodic bacterial communities in microbial fuel cells. ISME J. 6, 2002-2013.

Zhang, L., Li, C., Ding, L., Xu, K., Ren, H., 2011. Influence of initial pH on the performance and anodic microbes of fed-batch microbial fuel cells. J. Chem. Technol. Biotechnol. 86, 1226-1232.

Zhang, G., Zhao, O., Jiao, Y., Wang, K., Lee, D.-J., Ren, N., 2012. Efficient electricity generation from sewage sludge using biocathode microbial fuel cell. Water Res. 46, 43-52.

Zuo, Y. Pin-Ching Maness, Logan, B., 2006. Electricity production from steamexploded corn stover biomass. Energy Fuel 20, 1716-1721. 